\title{
Do-it-Yourself Microfluidics and Possibilities for Micro PIV
}

\section{Andreja S. Jović \\ Research Scientist CytoMag LLC} Sunnyvale, California

\section{Milan M. Raković}

Teaching Assistan University of Belgrade

Faculty of Mechanical Engineering

\section{Đorđe S. Čantrak}

Assoc. Professor

University of Belgrade

Faculty of Mechanical Engineering

Novica Z. Janković

Research Assistant University of Belgrade

Faculty of Mechanical Engineering
We present a method for microfluidic channel fabrication that has the following advantages compared to conventionally-used methods: technical simplicity, dramatically lower fabrication costs, and fabrication time. The method entails printing channel designs on a thermoplastic film from a LaserJet printer. Exposure to high temperatures elicits isotropic shrinkage of the film (in the $x$-y plane), in addition to thickening (in the z-direction), resulting in a positive relief mold. The microfluidic channel design of the mold is then transferred to a polydimethyl siloxane (PDMS) chip through soft lithography, resulting in a ready-to-use microfluidic chip. Through this approach, chips with complex channel geometries can be generated with low cost equipment and in as little as a couple hours. Flow visualizations from several chips from the "Do-it-yourself Microfluidics Workshop", held at the Faculty of Mechanical Engineering Univeristy of Belgrade, are presented in this paper. We also discuss possibilities for adapting micro particle image velocimetry (PIV) measurements to channel designs on PDMS-based microfluidic chips using the fabrication method delineated here.

Keywords: microfabrication, microfluidics, Shrinky Dink, rapid prototyping, PDMS, micro PIV

\section{INTRODUCTION}

Microfluidics entails manipulation of fluids on the micro-scale, ususally for engineering or biomedical purposes. Microfluidic devices are produced in various ways. Traditional methods involve photolithography for mold production [1]. This procedure requires a clean room and expensive equipment. It is also a timeconsuming method.

Usage of thermoplastic materials abrogates the need for a clean room and expensive equipment, and drastically reduces fabrication time [2]. When channel designs are printed on thermoplastic sheets and then exposed to high temperatures, the sheets shrink isotropically (in the $x-y$ plane) and increase in height along with the printer toner (in the z-direction). The height of the toner is on the order of tens of microns, a height favorable for use as a mold for microfluidic designs. These characteristics have a positive impact on the development of microfluidics in two ways: resourcelimited laboratories can easily produce microfluidic chips and the time from idea to chip is reduced to a matter of a couple hours.

Here we present the results of the "Do-it-yourself Microfluidics Workshop" held at the Faculty of Mechanical Engineering University of Belgrade (FME UB) on September 20th 2017. Twenty-seven participants from seven scientific institutions from Serbia and one from Montenegro took part.

Received: March 2018, Accepted: May 2018

Correspondence to: Dr. Đorđe Čantrak

Faculty of Mechanical Engineering,

Kraljice Marije 16, 11120 Belgrade 35, Serbia

E-mail: djcantrak@mas.bg.ac.rs

doi:10.5937/fmet1804525J

(C) Faculty of Mechanical Engineering, Belgrade. All rights reserved

\section{MICROCHANNEL DESIGN PROCEDURE}

The protocol described here is a variation of that presented by Hemling et al. [3]. The geometry of 2D microchannels are designed using Microsoft Powerpoint (PPT). The microchannel shapes can vary in their complexity (Fig. 1). Some microfluidic templates prepared for the workshop are presented in Fig. 1. The polystyrene thermoplastic sheets used for the workshop are called Shrinky Dinks (SD), a children's toy, which, when heated, shrinks to small hard plates preserving the shape of the drawn object. Workshop participants prepared their own microchannel templates. First, sketches were made by hand, and afterwards in PPT. They were instructed to prepare three designs in duplicate as indicated in Fig. 1. Paper format A4 is recommended for the SD sheets. Sketches should be positioned in the center of each field, so they are not damaged during cutting. The quality of the designs printed on the SD sheets depends highly upon printer resolution. Design templates were printed twice in case accidents with the printer were encountered (Fig. 1).

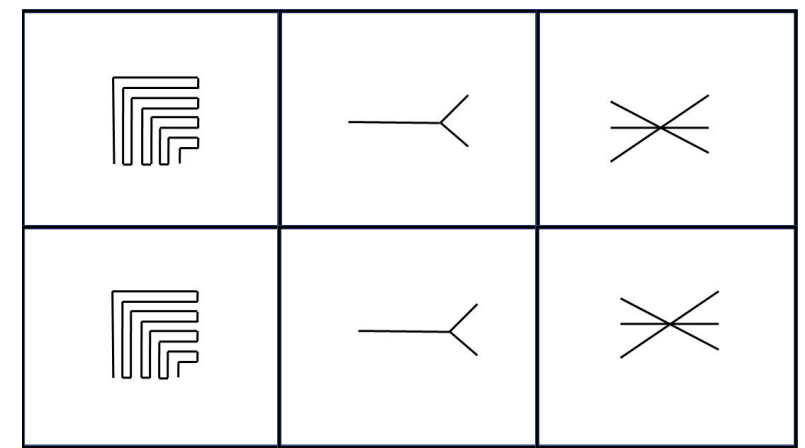

Figure 1. ShrinkyDink microfluidic templates prepared for workshop 
It is suggested to print the templates first on paper, instead of the SD sheets, in order to get a sense of how the design will look on the SD sheets and to assess printer quality. The designs should be evenly printed without any scratches. The templates containing the microfluidic designs are printed on the SD sheets by LaserJet printer. We used an HP LaserJet 1010 for the workshop. The SD sheets were manufactured by Grafix (version: Clear, Catalog No.: KSF50-C).

The sheets are then heated uniformly, in order to induce shrinking. In paper [2], shrinkage occurs after three to five minutes in an oven heated to $163^{\circ} \mathrm{C}$. The authors report that unwanted deformations could be minimzed by positioning the sheet on a glass plate. In order to achieve uniform heating of the SD sheet, we used hot oil. A beaker of hot oil was positioned on a hotplate where the temperature is controlled and adjusted to $150{ }^{\circ} \mathrm{C}$. The SD sheets are carefully positioned in the bowl with the heated oil. Tweezers could be used for this operation, but caution is needed to perform this task without damaging the printed designs.

The SD sheet is positioned so that the printed side is facing upward, otherwise the printed design can smear when exposed to high temperatures. Isotropic shrinkage is almost instantaneous. Length and width of the SD sheet is decreased by about $60 \%$, while its thickness is increased approximately seven times. For this workshop, sheets of $0.25 \mathrm{~mm}$ thickness were used. Fig. 2 depicts an SD sheet with microfluidic design prior to (left side) and after heating in hot oil (right side). Shrinkage of both dimensions ( $x-y$ plane) of this sheet was $61 \%$. A similar design to that of Fig. 2 was shrunk by $64 \%$ upon exposure to hot oil, indicating that shrinkage was consistent.

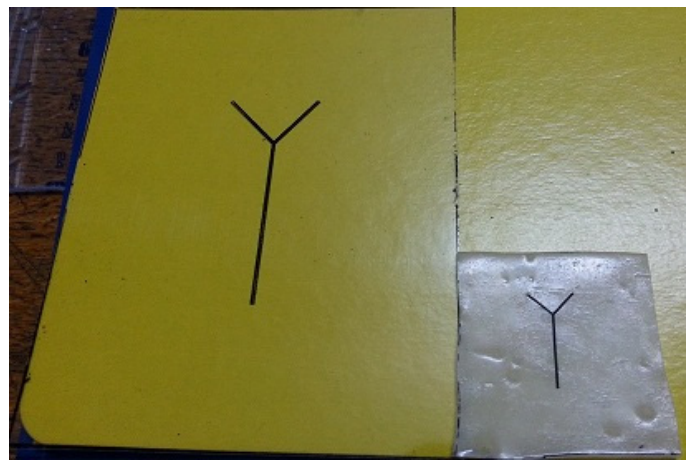

Figure 2. The SD original design (left) and the shrunken design (right)

While it is still in the hot oil, the SD sheet is positioned in the center of the glass plate by use of tweezers. The sheet is removed so that the ink trace is not in the contact with the glass plate. Another glass plate is positioned on top of the shrunken SD sheet, in order to eliminate possible deformations in the process of sheet solidification upon cooling. After one minute, the sheet is cooled and solid. The whole procedure for a rapid and non-photolitographic approach to microfluidic pattern generation is presented in Fig. 3 .

The advantage of using oil, instead of the oven for heating the SD sheet, is to minimize deformations and provide a uniform, compact heating area. The oil should be carefully removed from the mold afterwards, by washing with water and soap, and subsequently rinsed and dried. The SD sheet can now be thought of as a mold with positive relief features.

The mold is placed in a metal baking dish and is covered with polydimethyl siloxane (PDMS), which is prepared in a few steps. In a plastic cup, sylgard base is combined with crosslinker in a proportion of ten to one. The contents should be carefully mixed using a tongue depressor. The container is then positioned in a desiccator, where the vacuum removes all the air bubbles from the PDMS that appeared during mixing. Bubble removal lasts for about thirty minutes.

Once the PDMS is ready, it can be poured on top of the mold so that it is several millimeters thick. The baking dish with the mold and PDMS is positioned, afterwards, in an oven pre-heated to $100{ }^{\circ} \mathrm{C}$. Baking lasts for about thirty minutes, and results in complete PDMS curing. The cured PDMS now contains a negative relief of the microfluidic design, which was transferred to it from the postive relief mold. A scalpel is used for carefully separating the PDMS from the mold. The thick black lines around the designs in Fig. 1 serve as guides for cutting the PDMS from the mold. An added advantage of the protocol presented here is that the PDMS does not stick to the mold, which is not the case for silicon molds created through photolithography.

A biopsy punch is used for making inlets and outlets on the PDMS microchannel (Fig. 4). Openings must be clean without any debris. The resulting PDMS microfluidic chip is then attached to a flat glass plate using double sided tape, such that the microchannel side is facing downwards.

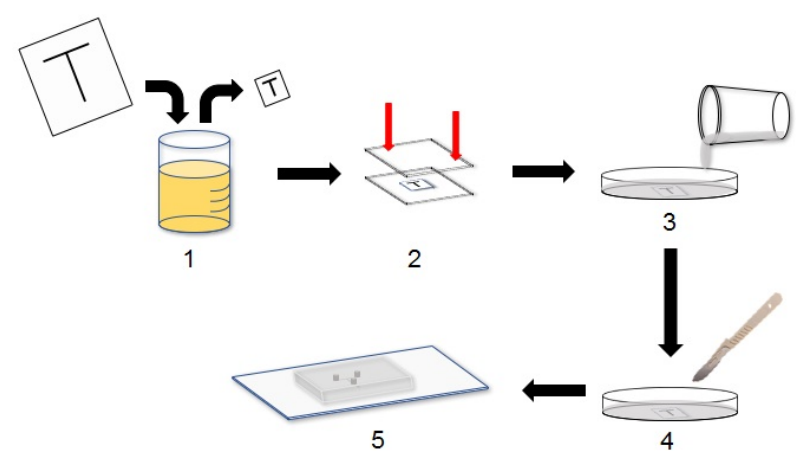

Figure 3. Microchannel design procedure: 1 - the printed design is shrunk in hot oil, 2- the design is flattened, 3PDMS is cast on the mold, 4- the cured PDMS with the design imprinted in it is cut out and 5- holes are punched in the PDMS and it is attached to a glass slide, ready for use

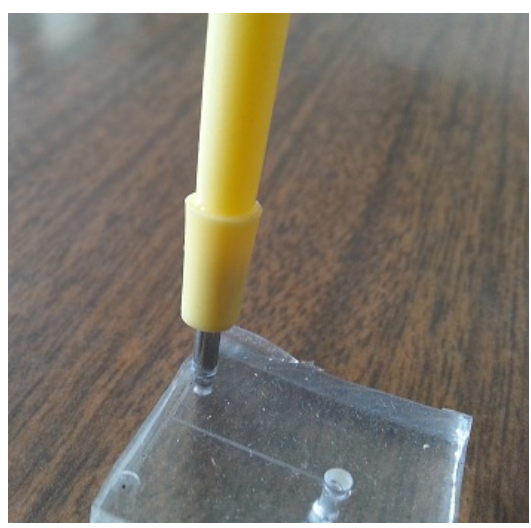

Figure 4. Biopsy punch 
Microchannel heights can be modified by printing the same design multiple times on the same SD sheet. However, positioning is very important in this case. The greater the height of the printer toner on the SD sheets, the greater the height of the resulting PDMS microchannels. Heights of $80 \mu \mathrm{m}$ are possible, which is sufficient for studying bioflows or fluid flow with living cells.

In fact, the height of the channel is approximately 40 $\mu \mathrm{m}$, though it is highly dependent upon the printer used. If the same sheet is printed upon multiple times, the height can be increased up to approximately $100 \mu \mathrm{m}$ [2].

Various microchannel molds, manufactured by the participants, in the "Do-it-yourself Microfluidics Workshop", FME UB, are presented in Fig. 5.

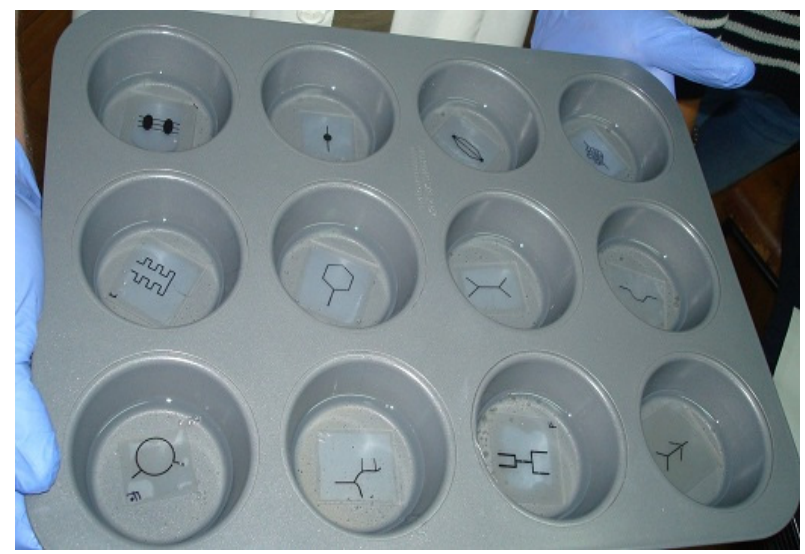

Figure 5. Representative individual microchannel molds in a baking dish, taken from the "Do-it-yourself Microfluidics Workshop", FME UB

The presented procedure could be used also for designing multi-layer microfluidic chips. The procedure is repeated for creation of PDMS parts that can be carefully positioned one above the other and afterwards connected together with vertical channels by use of a biopsy punch. The procedure presented in [4] could be used for more complex geometries.

Without any oxygen plasma treatment, the RMS roughness of PDMS measures $3.6 \mathrm{~nm}$ [5].

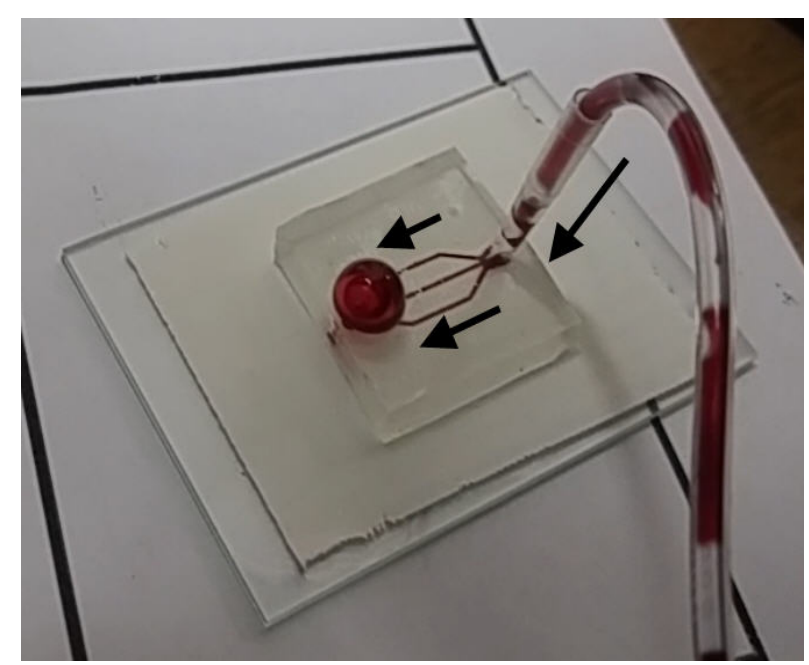

Figure 6 Flow visualization at the workshop

\section{FLOW VISUALIZATION}

When the PDMS chip is manufactured, together with inlet and outlet openings and fixed to a glass plate by tape, it is ready to be used. Food dye mixed with distilled water is used for flow visualization, while a syringe pump is used to control the flow rate. This setup is presented in Fig. 6.

A silicon hose with a $200 \mu \mathrm{L}$ serrated pipette tip is positioned on the inlet created by the biopsy punch. The silicon hose is attached to the syringe pump. Arrows denote flow direction. Fluid flow is easily observed due to the transparency of PDMS.

\section{MICRO PARTICLE IMAGE VELOCIMETRY}

Velocity measurements can be performed on these microfluidic chips by applying micro particle image velocimetry (PIV) [6]. Micro PIV is a nonintrusive fluid flow measurement technique based on image analysis of light illumination of the seeded flow. Flow is seeded with $1 \mu \mathrm{m}$ orange or red fluorescing polystyrene or polymer microspeheres. The microspheres can be used also for flow visualization, but they are much more expensive than food dye. Two subsequent images are correlated and velocity field is derived. The greater the number of image pairs, the better the assessment of the velocity field. The micro PIV arrangement with PDMS chip is presented in Fig. 7.

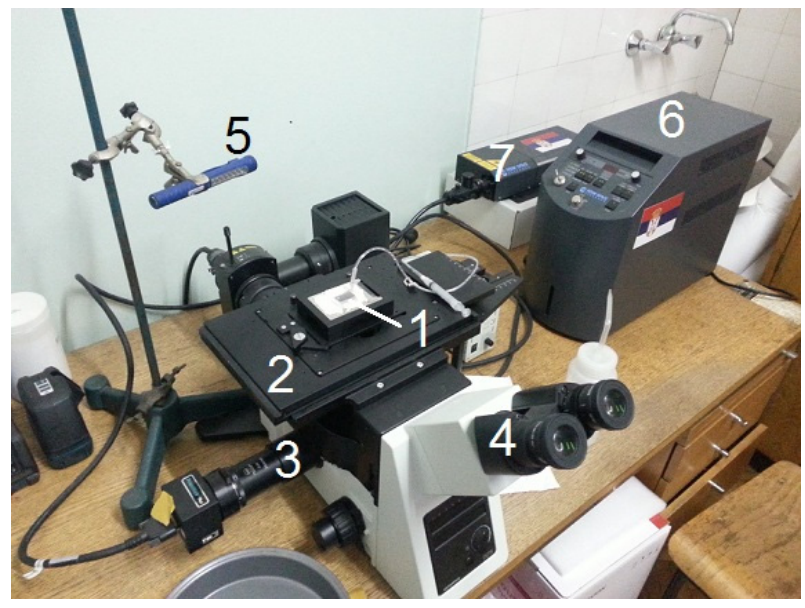

Figure 7. Micro PIV arrangement: 1- microchannel in position for measurements, 2- movable table attached to the microscope, 3- CCD camera, 4- inverted based microscope, 5- LED lamp, 6- laser power supply and 7- dual head Nd:YAG laser

In Fig. 7 depicts the micro PIV setup with inverted microscope (4) and epi-fluorescent attachments for micro PIV measurements using fluorescent micro-particles. The microscope is connected with a double-pulsed $\mathrm{Nd}$ :YAG (neodymium-doped yttrium aluminum garnet, $\mathrm{Nd}: Y 3 \mathrm{Al}$ (5012) laser (7) by optical cable. Visualization could be also done with the help of an LED lamp (5) and cameras which could be attached to the microscope occulars. The microscope (4) has proper filters to control the light going into the sample and minimize potential hot spots of the laser light. It has objectives for $4 x, 10 x, 20 x$ and 40x magnification.

The inverted microscope is equipped with an Fmount camera adaptor. A TSI PowerView Plus 2MP CCD (charge coupled device) camera is used for this application. It can provide $1600 \times 1200$ pixel resolution. It operates at 32 frames per second and provides 12-bit 
output. The seutp also includes a synchronizer with computer and adequate software for data acqusition and analysis (not pictured in Fig. 7).

The PDMS chip is positioned on a movable stage mounted on the inverted microscope. However, because of the opacity of the double-sided tape used to fix the PDSM microchip to the glass slide, micro PIV measurements are not possible. To overcome this limitation, the PDMS chip is attached with double-sided adhesive tape only on the edges of the channel to the glass plate (Fig. 8). While sealing is a problem in this situation, improvements are in preparation.

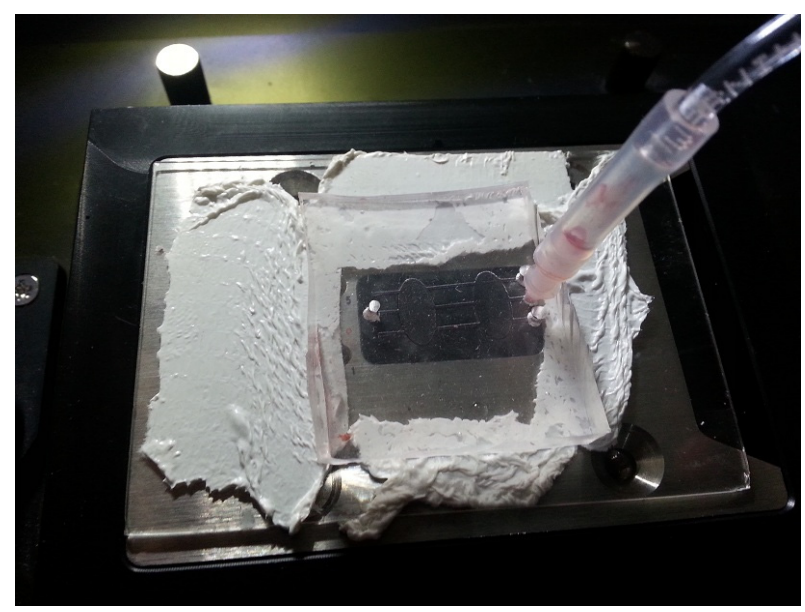

Figure 8. Positioning the manufactured microchannel for micro PIV measurements

Fluid flow simulations for different microchannel geometries, which could be manufactured in this way, are presented in [6].

In paper [7] is reported low cost approach for $2 \mathrm{D}$ measurement of velocity based on PIV. These results are comparable to laser Doppler velocimetry measurements. Further system developments and integration are planned. Applications for syringe pump movement control that can be used with this low cost PIV and PDMS chips are presented in [8].

\section{CONCLUSIONS}

Although in this paper are presented only experimental results, it is of interest to mention that various analytical solutions are obtained for flows in microchannels. Analytical solutions for rarefied gas flow at low Reynolds number in microchannels are presented in [9]. These solutions agree well with the experimental results presented in [10]. Performed experiments didn't provide velocity distributions, what could be a task for the micro PIV, although a hard one. "It is conceivable to use gaseous fluids, such as air, but $\mu$ PIV experiments using air have not been demonstrated successfully to date." [11]. Anyhow, a significant progress has been made in the last decade in application of micro PIV. It is widely used today in the study of the liquid and two-phase flows, but there are also breakthroughs in validation of slip-flow boundary condition in gas flows in microchannels.

Focus of this paper is an inexpensive, simple method for designing and creating microfluidic PDMS chips. Chips, fabricated using this method, can be designed, created and tested in a matter of hours, what is of great importance for a variety of experiments in microchannels.

Microfluidic devices of complex geometries can be fabricated using the method presented here, which includes various microchannel heights and circular microchannel cross-sections.

The application of hot oil for isotropically shrinking thermoplastic sheets, instead of using an oven, eliminates deformations which may occur in this stage of production.

The smallest dimension which could be generated with this procedure depends on the laser jet printer resolution.

In this paper are presented some of the results obtained at the workshop "Do-it-yourself Microfluidics Workshop" held at the FME UB. Flow visualization is demonstrated for one of the microchannel geometries. Food dye mixed with water is used for flow visualization.

Flow in these microchannels could be experimentally studied by use of micro PIV, which is the basis of future work in our lab.

\section{ACKNOWLEDGMENT}

This work is supported by the Ministry of Education, Science and Technological Development of Republic of Serbia, Project No. TR35046. Dr Andreja Jović was supported by the U. S. Embassy Belgrade under the umbrella of State Department U.S. Speaker Program. We are, also, thankful to all participants of this workshop, especially to those who supported us with their equipment: Prof. Dr Ivanka Karadžić and Assist. Prof. Dr. Tatjana Đukić from Faculty of Medicine University of Belgrade (UB), Prof. Dr. Mirjana Kijevčanin, Prof. Dr. Bojana Obradović and Sci. Assoc. Dr. Jasmina Stojkovska from Faculty of Technology and Metallurgy UB, Prof. Dr Aleksandar Jovović and Assist. Prof. Dr. Mirjana Stamenić from Faculty from Mechanical Engineering UB and Research Fellow at BioSense Instiute Dr. Ivana Gađanski.

\section{REFERENCES}

[1] Xia, Y.N. and Whitesides, G.M.: Soft lithography, Angew. Chem., pp. 551-575, 1998.

[2] Grimes, A., Breslauer, D.N., Long, M., Pegan, J., Lee, L.P., Khine, N.: Shrinky-Dink microfluidics: rapid generation of deep and rounded patterns, Lab Chip, pp. 170-172, 2007.

[3] Hemling, M., Crooks, J.A., Oliver, P.M., Brenner, K., Gilbertson, J., Lisenksy, G.C., Weibel, D.B.: Microfluidics for High School Chemistry Students, J Chem Educ, 112-115, 2014.

[4] Rašljić, M., Građanski, I.I., Smiljanić, M.M., Janković, N.Z., Lazić, Ž., Cvetanović Zobenica, K.: Microfabrication of bifurcated microchannels with PDMS and ABS, in: Proceedings of $4^{\text {th }}$ International Conference on Electrical, Electronics and Computing Engineering, 05-08.06.2017, Kladovo, pp. MOI2.1 1-4. 
[5] Tan, S.H., Nguyen, N.-T., Chua, Y.C., Kang, T.G.: Oxygen plasma treatment for reducing hydrophobicity of a sealed polydimethylsiloxane microchannel, Biomicrofluidics, 4(3):32204, 2010.

[6] Jović, A., Janićijević, Ž., Janković, M.M., Janković, N.Z., Barjaktarović, M., Čantrak, Đ.S., Građanski, I.: Simulating fluid flow in "Shrinky Dink" microfluidic chips - potential for combination with low-cost DIY microPIV, IEEE EWDTS, pp. 494498, 2017.

[7] Janković, N.Z., Barjaktarović, M.C., Janković, M.M, Čantrak, Dj.S.: First steps in new affordable PIV measurements, in: Proceedings of the $24^{\text {th }}$ Telecommunications forum TELFOR 2016, 2223.11.2016., Belgrade, pp. 1-4.

[8] Kartali, A., Vuković, D., Janković, J., Rašković, M., Stanišić, A.: Application for syringe pump movement and microfluidic system fluid speed measurement, in: Proceedings of the $25^{\text {th }}$ Telecommunications forum TELFOR 2017, 21-22.11.2017, Belgrade, pp. 1-4.

[9] Radenković, D.R., Milićev, S.S., Stevanović, N.D.: Rarefied gas flow in microtubes at low Reynolds numbers, FME Transactions, Vol. 44, No 1, pp. 1015, 2016.

[10] Yang, Z. and Garimella, S.: Rarefied gas flow in microtubes at different inlet-outlet pressure ratios, Phys. Fluids, Vol. 21, 052005 , pp. 16, 2009.

[11] Wereley, S., Meinhart, C.: Micron-resolution particle image velocimetry, In: Breuer K.S. (eds) Microscale Diagnostic Techniques, Springer, Berlin, Heidelberg, pp. 51-112, 2005.

\section{ПРОИЗВОДЊА МИКРОКАНАЛА У ЛАБОРАТОРИЈИ И ПРИМЕНА МИКРО ПИВ-а}

\begin{abstract}
А. Јовић, М. Раковић, Ђ. Чантрак, Н. Јанковић
У односу на најчешће коришћене методе за производњу микроканала, поступак који је изложен у овом раду има следеће предности: једноставност, нижа цена потребне опреме и велика уштеда у времену.
\end{abstract}

Коришћењем ласерског штампача могуће је оставити траг мастила на листу од термопластичног материјала, у облику жељеног микроканала. Затим се лист убацује у загрејано уље где долази до изотропног смањивања његове дужине и ширине, и истовремено до повећавања дебљине. На тај начин се добија калуп. Припремљена PDMS маса се излива на калуп и затим пече.

Након печења, калуп се одваја од PDMS масе у којој ce сада налази удубљење које представља микроканал. Када се уређај причврсти за подлогу, и када се направе улазни и излазни отвори, спреман је за коришћење. На овај начин могуће је направити веома сложене микроканале променљивих димензијама, коришћењем опреме која није скупа и у веома кратком временском року.

У оквиру рада су приказане и визуализације струјања у каналима који су направљени у оквиру радионице "Do-it-yourself Microfluidics Workshop" која је одржана на Машинском факултету Универзитета у Београду. Дат је и кратак осврт на могућности примене микро ПИВ мерне технике. 